\title{
CHARACTERIZATION OF NEW AND RETRIEVED TITANIUM BIOMATERIAL FOR DENTAL IMPLANTS
}

\author{
KARAKTERIZACIJA BIOMATERIALOV NOVIH IN \\ UPORABLJENIH ZOBNIH VSADKOV
}

\author{
Sonja Žarković Gjurin ${ }^{1 *}$, Monika Jenko² ${ }^{2}$ Črtomir Donik ${ }^{2}$, Čedomir Oblak ${ }^{1}$ \\ ${ }^{1}$ Department of Prosthodontics, Faculty of Medicine, University of Ljubljana, Slovenia, Vrazov trg 2, \\ 1000 Ljubljana, Slovenia \\ ${ }^{2}$ Institute of Metals and Technology, Lepi pot 11, 1000 Ljubljana, Slovenia
}

Prejem rokopisa - received: 2020-06-09; sprejem za objavo - accepted for publication: 2020-07-25

doi:10.17222/mit.2020.114

\begin{abstract}
Dental implants serve as a reliable treatment option for replacing missing teeth. The important properties for implant materials are, besides biocompatibility, adequate strength, corrosion, wear and fracture resistance. The most important step in the stability of the implant is a structural and functional connection between the implant's surface and the newly formed bone, which is called osseointegration. It comprises a cascade of complex physiological mechanisms. The implant's surface characteristics and roughness are the most important in achieving the biomechanical concept of secondary stability. Nowadays, dental implants are produced from metals, ceramics or even polymers. Rehabilitations with titanium and titanium-alloy dental implants have shown long-term survival; therefore, they have become a gold standard to replace missing teeth. In the study we investigated new and retrieved dental implants and restorative materials, commercially pure titanium (cpTi), the Ti6Al4V alloy and CoCrMo alloys using light microscopy and scanning electron microscopy for the surface morphology and microstructure. Energy-dispersive spectroscopy was used for the chemical analyses. The results showed that the surfaces of the Ti and Ti6Al4V implants were roughened by corundum $\left(\mathrm{Al}_{2} \mathrm{O}_{3}\right)$ blasting, and the corundum contamination was found not only on the surface but also in the sub-surface of the new and retrieved dental implants. It is assumed that the retained corundum $\mathrm{Al}_{2} \mathrm{O}_{3}$ contamination on the surface of the Ti or Ti-alloy affects the osseointegration and longevity of the dental-implant rehabilitation.
\end{abstract}

Keywords: dental implant, corundum $\mathrm{Al}_{2} \mathrm{O}_{3}$, osseointegration, scanning electron microscopy, energy-dispersive X-ray spectroscopy

Zobni vsadki služijo kot zanesljiva metoda nadomestitve manjkajočih zob. Pomembne lastnosti materialov za zobne vsadke so biokompatibilnost, upogibna trdnost ter korozijska in obrabna odpornost. Stabilnost vsadka v kosti je omogočena zaradi procesa oseointegracije, ki pomeni strukturno in funkcionalno povezavo med površino vsadka in novonastalo kostjo. Oseointegracija poteka preko kaskade zapletenih fizioloških mehanizmov. Stabilnost zobnega vsadka je odvisna od površinske lastnosti in hrapavosti vsadka, kar zagotavlja dobro stabilnost v čeljustni kosti. Sodobni zobni vsadki so izdelani iz kovin, keramike ali celo polimerov. Zobni vsadki iz titana in njegove zlitine, predstavljajo zanesljivo oskrbo manjkajočih zob z visoko stopnjo preživetja. $\mathrm{V}$ študiji smo preiskovali nove in odstranjene zobne vsadke ter material za protetično oskrbo, izdelane iz komercialno čistega titana - cpTi, zlitine Ti6A14V in CoCrMo z metodami svetlobne mikroskopije, vrstične elektronske mikroskopije za površinsko morfologijo in mikrostrukturo ter energijske rentgenske disperzijske spektroskopije za kemijsko analizo. Rezultati prikazujejo delce korunda $\left(\mathrm{Al}_{2} \mathrm{O}_{3}\right)$ na površini titanovih vsadkov in vsadkov iz zlitine Ti6Al4V. Sledi kontaminacije $\mathrm{s}$ korundom so bile ugotovljene tudi v materialu pod površino novih in odstranjenih zobnih vsadkov. Korund na površini zlitine titanovih zobnih vsadkov lahko vpliva na proces oseointegracije in zmanjša življensko dobo zobnih vsadkov.

Ključne besede: zobni vsadek, korund $\mathrm{Al}_{2} \mathrm{O}_{3}$, oseointegracija, vrstična elektronska mikroskopija, energijska rentgenska disperzijska spektroskopija

\section{INTRODUCTION}

An implant is defined as a biomaterial that is inserted either partially or completely into the body for therapeutic, diagnostic or prosthetic purposes. ${ }^{1}$ Dental implants have been widely used for the oral rehabilitation of partially or fully edentulous patients, as they serve as replacements for the roots of missing natural teeth. ${ }^{1}$ The surface property of dental implants has been identified as the leading factor that influences the osseointegration of an implant and therefore the success and longevity of the implant. ${ }^{1,2}$

*Corresponding author's e-mail:

sonja.zarkovic@mf.uni-lj.si (Sonja Žarkovič Gjurin)
Nowadays, 1300 different dental implant systems exist, varying in shape, dimensions, bulk and surface materials, thread design, implant-abutment connection, surface topography, surface chemistry, wettability and surface modification. ${ }^{3}$ In general, the long-term survival rate of titanium dental implants is excellent; however, implant failures still occur. ${ }^{3}$ Due to insufficient osseointegration within the first few months, primary implant failure occurs in 1-2\% of patients. ${ }^{3}$ In about $5 \%$ of patients, secondary implant failure develops several years after successful osseointegration, commonly caused by peri-implantitis. ${ }^{3}$

Once a dental implant is produced, it is cleaned and polished, followed by roughening of the surface via one or more modification techniques. ${ }^{1}$ Sandblasting is the most common and basic treatment technique used for the 


\section{S. ŽARKOVIĆ GJURIN et al.: CHARACTERIZATION OF NEW AND RETRIEVED TITANIUM BIOMATERIAL ...}

modification of a surface. ${ }^{1}$ Sprayed corundum particles can create deep crevices and an average profile roughness of 1-2 $\mu \mathrm{m} .{ }^{3}$ This range of microtopography seems to provide an optimal degree of roughness to promote excellent osseointegration. ${ }^{4}$ Osseointegration consists of a cascade of complex physiological mechanisms, which are similar to direct fracture healing. ${ }^{3}$ The surface topography of an implant is crucial for the adhesion and differentiation of osteoblasts during the osseointegration. ${ }^{3}$ The study of different surface treatments has been well documented in the literature; therefore, the presence of residuals of alumina embedded on the surface of a dental implant is regarded as a potential risk for long-term osseointegration. ${ }^{5}$

The aims of the present study were:

(I) a detailed surface characterization is required for a better understanding and exploitation of the surface properties of dental implants;

(II) the microstructure of dental implants is a neglected factor in implant design; and

(III) a detailed microstructure characterization of prematurely failed dental implants.

\section{EXPERIMENTAL PART}

\subsection{Materials and methods}

The two retrieved dental implants (sample 1 and sample 2) were selected from revision procedures performed at the Department for Prosthetic Dentistry, Medical Faculty, University of Ljubljana. We also investigated two new dental implants (sample 3 and sample 4) of the producer Ankylos Friadent, Dentsply Sirona for comparison.

The surfaces of the new and retrieved dental implants were examined.

All the retrieved dental implants were sent for sonication in Ringer's solution for microbiological analysis and afterwards for cleaning and sterilization. Next, they were dried and stored in steam-sterilized paper bags. All the retrieved dental implants were cleaned according to standard procedures at the Microbiology Department of the Medical Faculty, University of Ljubljana, which consists of immersion in $2 \%$ micro-soap solution, followed by acetone, isopropanol $(\mathrm{xN}), 95 \%$ ethanol $(\mathrm{xN})$, and deionized water $(\mathrm{xN}) ;(\mathrm{xN})$ is the number of repeated processes. Sterilization was performed by autoclaving according to a standard protocol at $120{ }^{\circ} \mathrm{C}$ and a pressure of 1.25 bar for $20 \mathrm{~min}$. Afterwards, they were dried and stored in serialized bags and kept in a dry place.

Samples for the bulk and surface microstructure analyses and for the surface-chemistry analyses were prepared by standard metallographic procedures. Samples for the bulk and surface microstructure characterizations of cpTi (commercially pure $\mathrm{Ti}$ ), the Ti6Al4V alloy and the CoCrMo were cut from the new and retrieved dental implants using a water-cutting machine. Samples were ground and polished using Struers devices (Ballerup, Denmark).

\subsection{Scanning electron microscopy (SEM) analysis}

The cross-sections of the new and used dental implants were recorded with a Tagarno FHD Trend digital microscope at low magnifications. For the morphology, microstructure and chemistry the samples were analyzed using a field-emission scanning electron microscope (ZEISS crossbeam 550 FIB-SEM, Carl Zeiss AG, Oberkochen, Germany). The instrument is equipped with secondary-electron (SE) and backscattered-electron (BE) imaging modes for analyses of the morphology of the samples and EDS (EDAX, Octane Elite, Draper, Cambridge, MA, USA) for analyzing the surface chemistry. For the SE and BE imaging an acceleration of $15 \mathrm{kV}$ at a current of approximately $2.0 \mathrm{nA}$ was used for a vacuum in the main chamber below $10^{-6}$ mbar. Energy-dispersive $\mathrm{x}$-ray spectroscopy (EDS) and EDS mapping were used for the elemental analyses of the surface (Octane Elite EDS System EDAX).

\section{RESULTS}

\subsection{Scanning electron microscopy (SEM)}

The surfaces of the $\mathrm{Ti}$ and $\mathrm{Ti} 6 \mathrm{Al} 4 \mathrm{~V}$ implants were roughened by sandblasting using corundum $\left(\mathrm{Al}_{2} \mathrm{O}_{3}\right)$. On the retrieved implants (sample 1 and sample 2) $\mathrm{Al}_{2} \mathrm{O}_{3}$ contamination was detected. The new implant (sample 3) retained no $\mathrm{Al}_{2} \mathrm{O}_{3}$ contamination. Contamination with

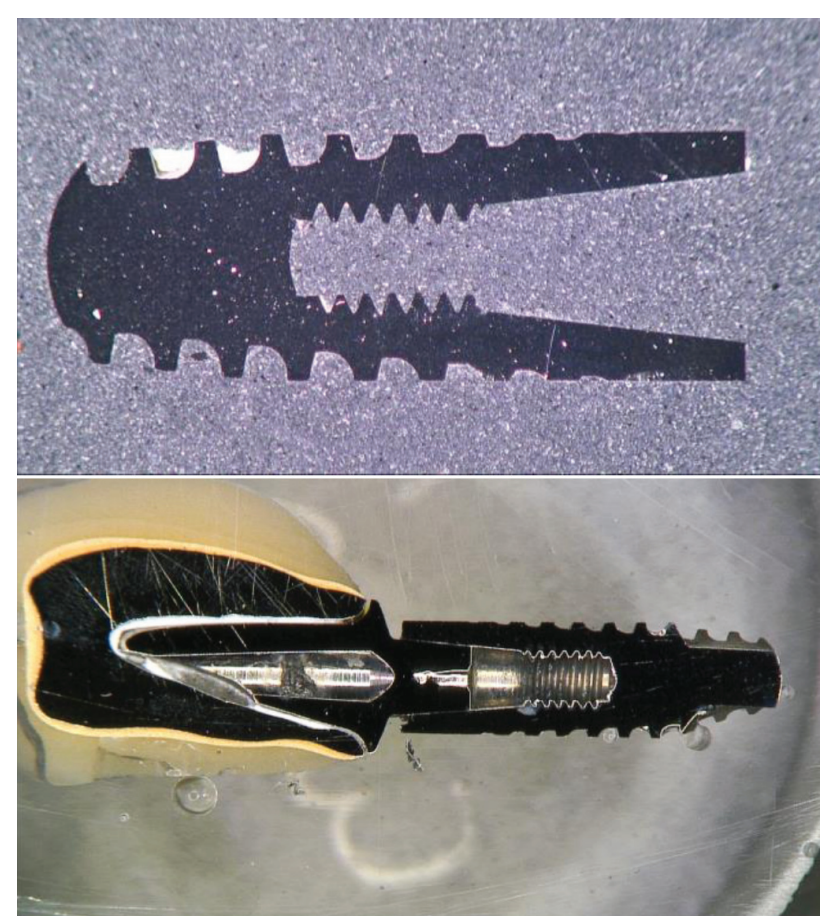

Figure 1: Cross-section of retrieved implant (sample 1) and retrieved dental implant with metal implant abutment and metal ceramic crown (sample 2) recorded with digital microscope Tagarno FHD Trend 


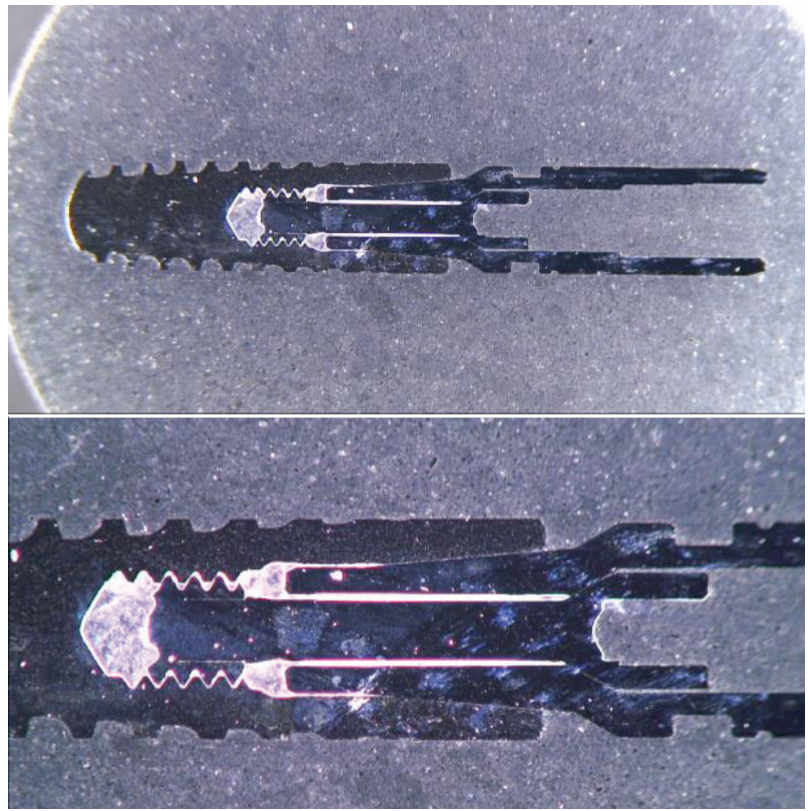

Figure 2: Cross-section of new and retrieved dental implant (sample 3) at two different magnifications recorded with digital microscope Tagarno FHD Trend.

$\mathrm{Al}_{2} \mathrm{O}_{3}$ was found not only on the surface but also in the bulk of the implant, close to the surface of the retrieved

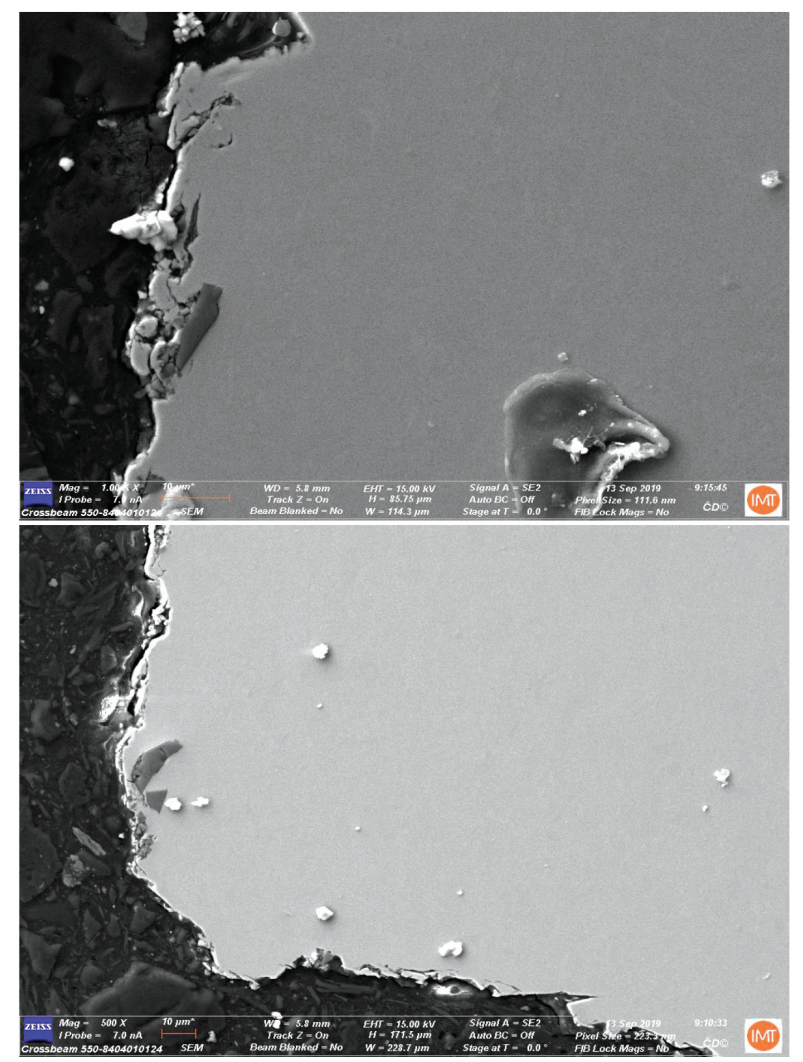

Figure 3: SE image of the cross-section of a new dental implant (sample 1), surface and sub-surface corundum contamination (darker grey, arrow pointing) was found at different magnifications, darker grey areas are retained corundum particles from the blasting procedure of the surface.
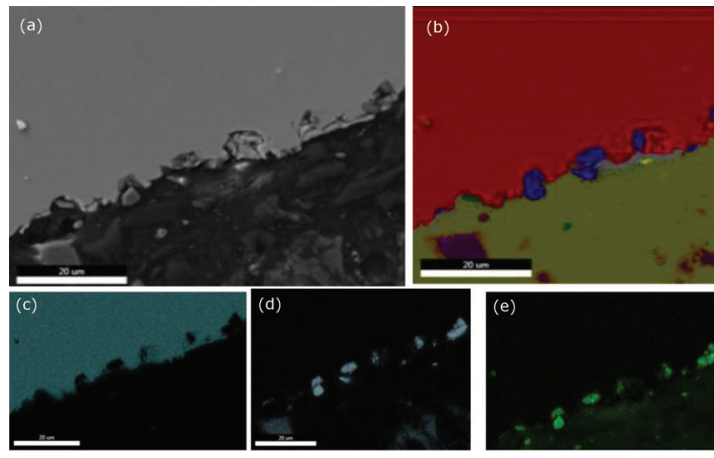

Figure 4: SEM/EDS mapping of a cross-section of the new dental implant sample: a) SE image, b) EDS mapping showing the distribution of elements $\mathrm{Ti}$ (red) and $\mathrm{Al}_{2} \mathrm{O}_{3}$ (blue), c) Ti matrix (light green), d) $\mathrm{Al}$ (light blue) and e) $\mathrm{O}_{2}$ (green)

dental implant. Figure 1 showed a cross-section of retrieved implants (a) and a cross-section of the implant restored with the Ti6Al4V screw, CoCrMo abutment and cemented Co $\mathrm{Cr}$ metal ceramic crown.

Additional SE images (Figures 3 and 6) with EDS area analyses (Figure 6) and EDS mappings (Figures 4 and 5) were performed with a scanning electron microscope for an elemental distribution of the implant's cross-section.

Figure 3 reveals the embedding of the corundum contamination in the size of a few tens of microns below the surface observed on different areas of the new dental implant in the cross-section.

Figure 4 represents the mapping of the cross-section to corroborate the surface and sub-surface contamination with $\mathrm{Al}$ and $\mathrm{O}\left(\mathrm{Al}_{2} \mathrm{O}_{3}\right)$ after the surface treatment.

On the other hand, Figure 5 shows the EDS mapping of the CoCr alloy abutment with porcelain fused to metal crown on the top with the elemental distribution of the $\mathrm{Ti}, \mathrm{Co}$, and $\mathrm{Cr}$ elements. Images on Figure 5 represent

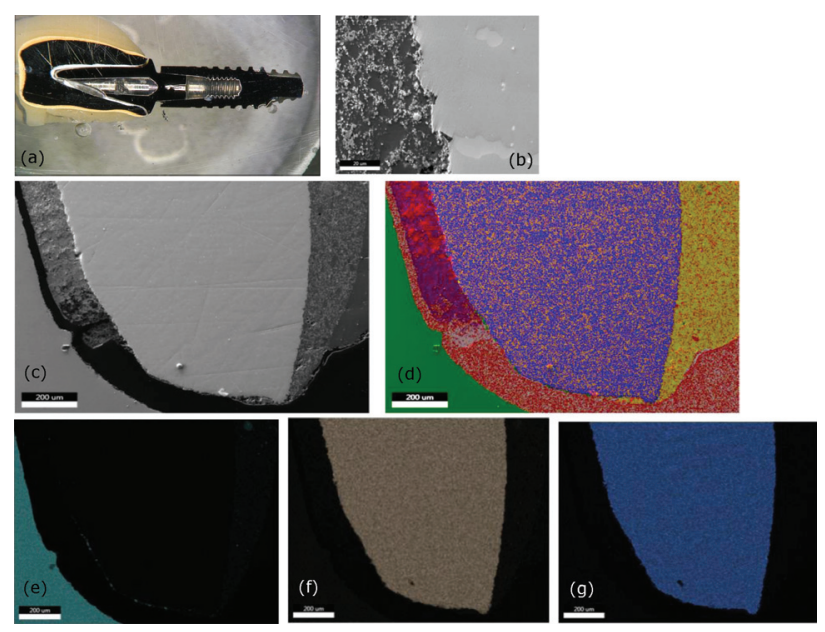

Figure 5: SEM/EDS mapping of: a) retrieved integrated implant, CoCrMo abutment and ceramic crown, sample 2, b) SE of cross-section, detail of SE image, c) shows CoCrMo microstructure; d) SEM/EDS mapping of retrieved dental implant 2, distribution of elements show e) Ti (green), f) Cr (brown) and g) Co (blue). 

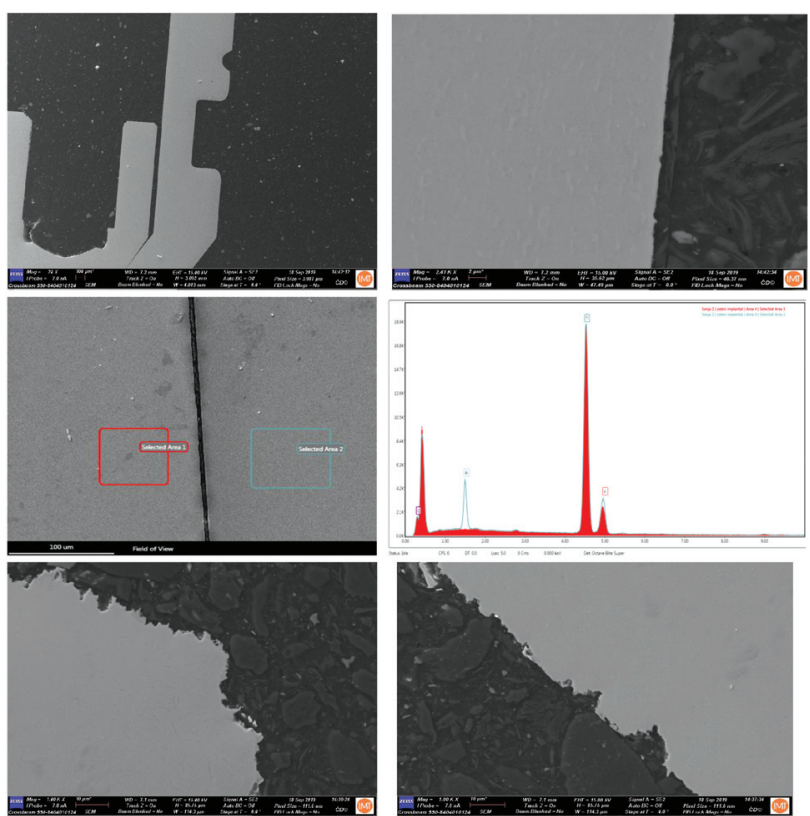

Figure 6: SE image of a cross-section of a new dental implant sample 2 , a) detail of implant, b) surface at higher magnification with no corundum contamination, c) joint of cpTi part (red and Ti6Al4V (blue) and d) sum EDS spectrum of cpTi and Ti6Al4V part from selected areas; EDS shows two different material cpTi (red square) and Ti6Al4V(blue square), e) and f) cross-section of surface at higher magnification with no $\mathrm{Al}_{2} \mathrm{O}_{3}$ residue.

an integrated implant with a stereo microscope Figure $\mathbf{5 a}$, while Figures $\mathbf{5 b}$ to $\mathbf{5 g}$ shows the microstructure with SEM and EDS mapping of smaller area on the surface of the $\mathrm{CoCr}$ alloy. Figures $\mathbf{5 f}$ and $\mathbf{5 g}$ show the evenly distributed $\mathrm{Co}$ and $\mathrm{Cr}$ and that $\mathrm{Ti}$ is not in touch with the $\mathrm{CoCr}$ alloy in the middle since the ceramic separates the $\mathrm{CoCr}$ alloy and the $\mathrm{Ti}$.

Figure 6 reveals the SE image of the cross-section of a different surface of the implant. Figure 6 a represents the screw joint of cp Ti and TiAlV alloy - which is represented in Figure 6c and the spectra in Figure 6d. Figure $6 \mathbf{b}$ reveals the microstructure of the TiAlV alloy, while Figures 6e and 6 f represent the cross-section with no additional $\mathrm{Al}_{2} \mathrm{O}_{3}$ contamination on either surface or subsurface areas as was observed in Figures 3 and 4 .

\section{DISCUSSION}

The presented results showed that the surfaces of the $\mathrm{Ti}$ and $\mathrm{Ti6Al4V}$ implants were roughened by $\mathrm{Al}_{2} \mathrm{O}_{3}$ blasting, and the surface contamination with $\mathrm{Al}_{2} \mathrm{O}_{3}$ residue was found not only on the surface but also in the subsurface of the retrieved dental implant. Sandblasting is a necessary step in the surface preparation of dental implants, as a simple and basic method that accelerates the osteoblast attachment and propagates the osseointegration, thus improving the initial stability. ${ }^{1,5}$ The surface composition and the implant biocompatibility can be changed by blasting the implants' surface with gritting agents made of materials other than the dental implant core material. ${ }^{5}$

Sandblasting changes the structure and also the surface chemistry, increases the wettability and the potential for early interaction of the dental implant surface with biological fluids. ${ }^{1}$ If the sand particles after sandblasting are not completely removed from the implant body, they can cause inflammation ${ }^{1}$ As observed from the SE images and SEM/EDS mappings, the $\mathrm{Al}_{2} \mathrm{O}_{3}$ residue is still present on the surface and just below the implant surface, which could also be a potential initiation point for corrosion. After sandblasting of the surface, it is of great importance for the $\mathrm{Al}_{2} \mathrm{O}_{3}$ residue to be removed before the implantation in the bone.

The configuration and conformation of cellular pseudopodi are important in cell adhesion, which seems to be enhanced by the surface roughness. ${ }^{6}$ Additionally, cells on the rougher surfaces release higher levels of factors, which are involved in the regulation of the bone formation. ${ }^{6}$ Therefore, it is not surprising that there was significantly less coronal bone loss around the sandblasted dental implants, which could be the result of the better osteoconductive properties of the sandblasted surfaces. ${ }^{6}$ The nature and texture of the surface of the dental implant largely control the response of the tissues to the implant. ${ }^{7}$ Textured implant surfaces exhibit more surface area compared to the smooth surfaces for integration with bone, they also allow the ingrowth of the tissues. ${ }^{7}$

Sandblasting with corundum $\mathrm{Al}_{2} \mathrm{O}_{3}$ is the preferred method for the modification of the surface of dental implants. ${ }^{1}$ Particles of different sizes provide regular roughness values, which cause the osteoblasts to change and bind to the bone. ${ }^{1}$ When using $\mathrm{Al}_{2} \mathrm{O}_{3}$, the potential risk of the presence of remnants of particles with the dissolution of $\mathrm{Al}$ ions into the host tissue cannot be excluded..$^{5,8-11} \mathrm{It}$ has also been reported that $\mathrm{Al}_{2} \mathrm{O}_{3}$ stimulates the flow of calcium from the bone. ${ }^{1,8-10}$ Aluminum can also compete with calcium in the healing implant bed. ${ }^{8}$ It has also been shown that aluminum can accumulate at the mineralization front and in the osteoid matrix., ${ }^{5,8}$ Aluminum ions can also inhibit the normal differentiation of the bone marrow stromal cells and normal bone deposition and mineralization. ${ }^{5}$ The presence of alloying elements in titanium alloys, such as Al, probably influences the adsorption of proteins on the surface and therefore modifies the surface-cell interaction. ${ }^{9-11}$

\section{CONCLUSIONS}

Retained $\mathrm{Al}_{2} \mathrm{O}_{3}$ contamination on the surface of Ti or a Ti alloy affects the osseointegration and longevity of the implant. On the surface of the new implants no $\mathrm{Al}_{2} \mathrm{O}_{3}$ contamination was detected, which indicated the use of another surface-roughening method. Our results on titanium dental implants are similar to the results of the study with explanted metallic endoprostheses. $\mathrm{TiO}_{2}$ blasting had positive effects on the osseointegration and 


\section{S. ŽARKOVIĆ GJURIN et al.: CHARACTERIZATION OF NEW AND RETRIEVED TITANIUM BIOMATERIAL ...}

on the biomechanical features of the implants; therefore, $\mathrm{TiO}_{2}$ blasting can be recommended instead of $\mathrm{Al}_{2} \mathrm{O}_{3}$ blasting.

\section{Acknowledgment}

This research was funded by the Slovenian Research Agency ARRS (P2-0132-Research Program Institute of Metals and Technology).

\section{Conflict of interest}

The authors declare they have no conflict of interest.

\section{REFERENCES}

${ }^{1}$ M. E. Yurttutan, A. Keskin, Evaluation of the effects of different sand particles that used in dental implant roughened for osseointegration, BMC Oral Health, 18 (2018) 1, 47, doi:10.1186/s12903-018 0509-3

${ }^{2}$ M. Rong, H. Lu, L. Wan, X. Zhang, X. Lin, S. Li, L. Zhou, Y. Lv, Y. $\mathrm{Su}$, Comparison of early osseointegration between laser-treated/ acid-etched and sandblasted/acid-etched titanium implant surfaces, J Mater Sci Mater Med, 30 (2018) 29, 43, doi:10.1007/s10856-0186049-1

${ }^{3}$ R. Smeets, B. Stadlinger, F. Schwarz, B. Beck-Broichsitter, O. Jung, C. Precht, F. Kloss, A. Groebe, M. Heiland, T. Ebker, Impact of Dental Implant Surface Modifications on Osseointegration, Biomed Res Int, (2016) 6285620, doi:10.1155/2016/6285620
${ }^{4}$ T. Albrektsson, A. Wenneberg, Oral implant surfaces: part 1- review focusing on topographic and chemical properties of different surfaces and in vivo responses to them, Int. J. Prosthodont, 17 (2004) 5, 536-543

${ }^{5}$ S. A. Gehrke, S. Taschieri, M. Del Fabbro, P. G. Coelho, Positive Biomechanical Effects of Titanium Oxide for Sandblasting Implant Surface as an Alternative to Aluminum Oxide, J Oral Implantol, 41 (2015) 5, 515-522, doi:10.1563/AAID-JOI-D-13-00019

${ }^{6}$ G. Orsini, B. Assenza, A. Scarano, A. Piattelli, Surface analysis of machined versus sandblasted and acid-etched titanium implants, Int. J. Oral Maxillofac. Implants, 15 (2000) 6, 779-784

${ }^{7}$ R. K. Alla, N. Ginjupalli, M. Upadhya, R. Shammas, R. K. Ravi, R. Sekhar, Surface Roughness of Implants: A Review, Trends Biomater. Artif. Organs, 25 (2011) 3, 112-118

${ }^{8}$ A. Piattelli, M. Degidi, M. Paolantonio, C. Mangano, A. Scarano, Residual aluminium oxide on the surface of titanium implants has no effect on osseointegration, Biomaterials, 24 (2003) 22, 4081-4089

${ }^{9}$ M. Jenko, M. Gorenšek, M. Godec, M. Hodnik, B. Šetina Batič, Č Donik, J. T. Grant, D. Dolinar, Surface chemistry and microstructure of metallic biomaterials for hip and knee endoprostheses, App Surf Sci., 427 (2018), 584-593

${ }^{10}$ K. Avsec, M. Jenko, M. Conradi, A. Kocijan, A. Vesel, J. Kovac, M. Godec, I. Belic, B. Š. Batič, Č. Donik, M.Gorenšek , B. Kocjancic, D. Dolinar, Surface Properties of Retrieved Cementless Femoral Hip Endoprostheses Produced from a Ti6Al7Nb Alloy, Coatings 9 (2019) 868, doi:10.3390/coatings9120868

${ }^{11}$ D. Dolinar, M. Jenko, M. Godec, M. Gorenšek, K. Avsec, B. Pompe, A. Cör, B. Kocjančič, Particulate debris from corundum-blasted titanium alloy cementless hip endoprostheses effecting aseptic loosening, AAOS 2020 Annual meeting, March 24-28, 2020, Orlando Florida, E-presentation 626 